\title{
Walter Kegel Christensen 25. maj 1942 - 18. oktober 2002
}

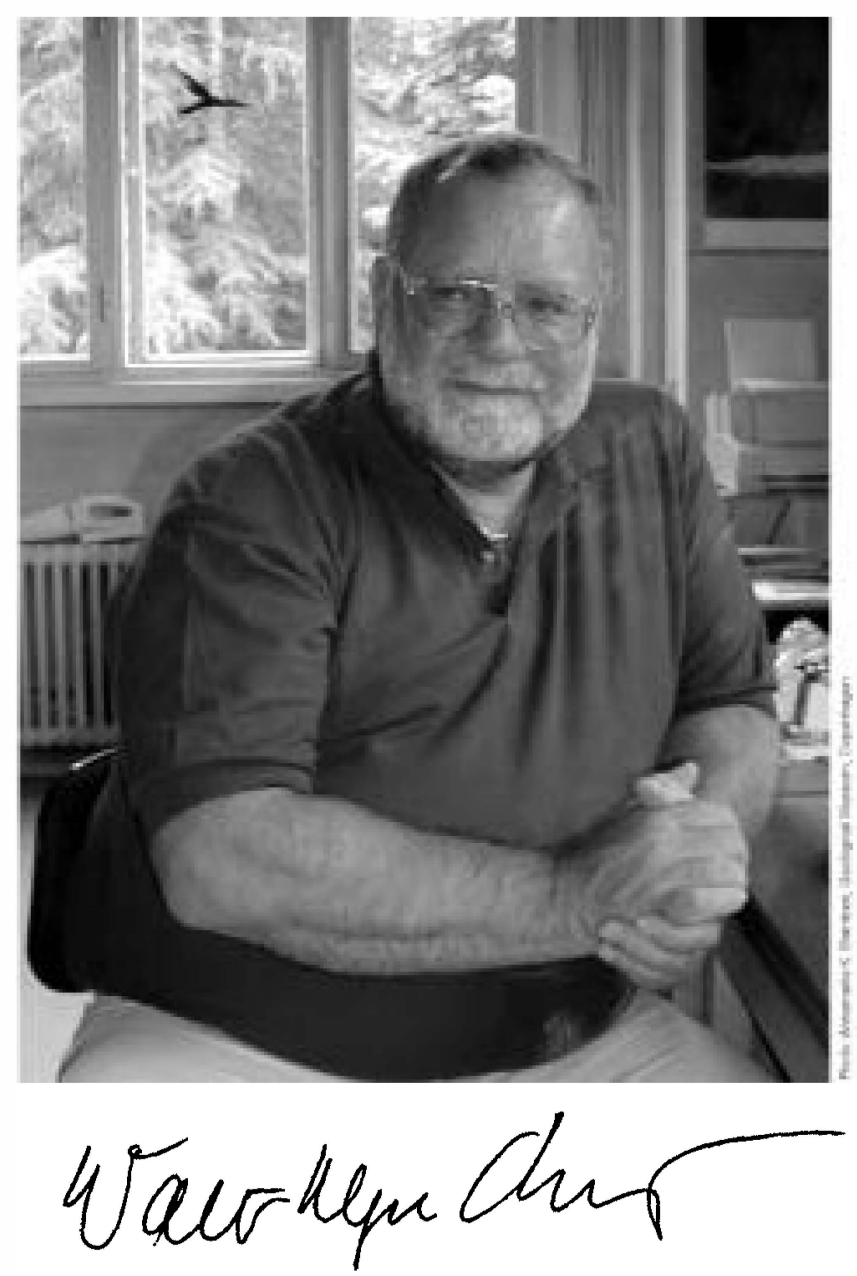

https://doi.org/10.37570/bgsd-2003-50-16

Docent, universitetslektor lic. scient. Walter Kegel Christensen ved Geologisk Museum, Københavns Universitet, afgik ved døden 18. oktober 2002 efter kort tids sygdom.

Walter Kegel Christensen blev født i København 1942. Han blev student fra Statens Studenterkursus 1962, og begyndte samme år at studere naturhistorie ved Københavns Universitet. En ny studie-ordning, der betød et brud med den gamle cand.mag. ordning, der sigtede mod en uddannelse til gymnasielærer, var indført året inden, men der var stadig en række støt-te- eller bifag. Studiet omfattede i de første år ligelige mængder af geologi, geografi, botanik og zoologi. Efter en omfattende og langvarig eksamen efter det andet studieår gik man videre de næste to år med enten zoologi og botanik eller som i Walters tilfælde geologi og geografi.

Walter holdt en pause midt i førstedelsstudiet på grund af ægteskab og fødsel af det første barn, Maja. Efter et års arbejde ved postvæsenet vendte han tilbage og gik ufortrødent videre med studierne.

Han var blevet interesseret i palæontologi, hvor der var et meget aktivt miljø omkring en række yngre lærere og specialestuderende. Da valget af specialeemne nærmede sig, besluttede han sig for at studere en spændende og på det tidspunkt meget velblottet Kridt lokalitet Ivö Klack i det nordvestlige Skåne. Ivö er en fossil klippekyst fra Campanien Etagen i Øvre Kridt, og i begyndelsen var hans arbejde bredt anlagt omfattende en karakteristik af hele faunaen. Snart valgte han imidlertid at studere en enkelt fossilgruppe, belemnitterne, taksonomisk og stratigrafisk. Dette tiltalte hans sans for systematik, men de økologiske aspekter af faunaen interesserede ham stadig. Den første sommers feltarbejde udførtes i samarbejde med Jørgen Butzbach, der nu er gymnasielærer i Rønne.

Bulletin of the Geological Society of Denmark . i 
De indsamlede store mængde af fremragende bevaret fossilmateriale repræsenterede en lang række dyregrupper.

Han fik således sin uddannelse som klassisk palæontolog på Geologisk Institut ved Københavns Universitet, hvor han var ansat som instruktor i palæontologi 1967-1969. Efter sin cand. scient. eksamen i 1970 blev han ansat som amanuensis-vikar og kandidatinstruktor ved Geologisk Institut, Århus Universitet i 1970-1972. I 1972 vendte han sammen med sin familie, som i mellemtiden var blevet forøget med en søn, Morten, tilbage til Geologisk Museum, Københavns Universitet, først som amanuensis og derefter adjunkt 1972-1974. I 1974 fik han tildelt lic.scient. (ph.d.) graden ved Københavns Universitet. Han blev fastansat som lektor fra 1974, og i 1988 blev han udnævint som docent.

Walters speciale, belemnitterne, var hovedhjørnestenen i resten af hans forskningsliv. Disse fossiler udgør en væsentlig del af grundlaget for den relative tidsskala for Kridt Perioden for 145 til 65 millioner år siden og er helt centrale for datering af lag fra dette tidsafsnit. I årenes løb blev han stille og roligt den ledende internationale ekspert indenfor udforskningen af belemnitternes udviklingshistorie gennem vedholdende professionelt arbejde udmøntet i en omfattende publikationsvirksomhed.

Walter havde stor fornøjelse af feltarbejde og omhyggelig indsamling af belemnitter fra Kridt lokaliteter overalt i Nordeuropa. Materialet anvendtes efter statistiske analyser og artsbestemmelse til præcis datering af de lag, de var fundet i. Han modtog også omfattende indsamlinger foretaget af kolleger til bestemmelse, datering og ofte monografisk bearbejdning.

I de tidlige år var vi en række jævnaldrende studerende, der alle arbejdede med forskellige dyregrupper fra Øvre Kridt i Danmark og den nærmere omegn. I samme periode startede Grønlands Geologiske Undersøgelse en femårs ekspedition til Scoresby Sund fjordkomplekset i Østgrønland. Kortlægningen af det store, næsten ukendte sedimentområde i Jameson Land blev udliciteret til en gruppe fra Københavns Universitet under ledelse af professor Tove Birkelund. Der var problemer med bemandingen og tre af de unge studerende, der arbejdede med Øvre Kridt faunaer deltog i den første ekspedition i 1968. Det var ud over Walter, Eckart Håkansson og undertegnede. Det var både godt og skidt. Vi havde hidtil kun prøvet selvstændigt arbejde i skrivekridt og kystnære kalkaflejringer i Danmarks og Skånes Øvre Kridt. Vores forudsætninger for arbejde i meget tykke lag af sandsten og skifre fra Trias og Jura i udstrakte blotninger var mildt sagt beskedne. Samtidig var moderne dynamisk sedimentologi endnu ikke 'opfundet', og vi kunne ikke gøre meget andet end at prøve at identificere en række stratigrafiske enheder - formationer - og så få dem kortlagt bedst muligt.

Walters deltagelse i ekspeditionen til det geologisk set ukendt land i Østgrønland i 1968 var ikke lige sagen. Hans storbybaggrund fornægtede sig ikke. Han var en typisk københavner og havde stort set ingen erfaring med udendørsliv, i særdeleshed ikke i arktiske ødemarker med vilde dyr og en total mangel på mennesker, huse eller andre ting, der kunne give en idé om afstande og størrelsesforhold. En morgen, da han stak hovedet af teltet veg han forskrækket tilbage med udbruddet til makkeren: »Eckart, der står et dyr derude! « og efter nok et blik på uhyret: »Det er en kat!«. Det var en sød lille nysgerrig blågrå polarræv. Walters feltarbejde blev efter denne chokerende oplevelse henlagt til mere civiliserede, lettilgængelige dele af verden, hvor der ikke rendte underlige uidentificerbare dyr rundt og forvirrede godtfolk.

Samtidig havde Tove Birkelund fået den lidt besynderlige idé, at tomandsholdenes sammensætning skulle ændres ved hvert lejrskift, således 'at vi alle sammen fik set alle formationer og alle områder'. Det betød, at Walter efter en første periode med Eckart i resten af sæsonen var holdkammerat med de tre kvinder i gruppen, henholdsvis Katharina Perch-Nielsen, Lone Malmros og Tove, noget ret revolutionært i de tider, og vel egentlig stadig ret usædvanligt, og vel næppe heller Walters kop te.

Walter var gennem hele sit professionelle liv ansat på Geologisk Museum ved Københavns Universitet. Det betød, at han ikke havde så megen kontakt med studerende som lærerne ved Geologisk Institut. Det var egentlig lidt synd, fordi han var meget hjælpsom og af naturen en meget lattermild og til tider lidt larmende person. Hvis studerende søgte hjælp og assistance med litteratur, bestemmelse af fossiler og adgang til samlingerne, fik de al den støtte, de havde brug for. Jeg har selv mange gange i årenes løb brugt ham som en mere eller mindre officiel medvejleder for studerende med speciale i stratigrafi og palæontologi.

I de systematisk-taksonomiske arbejder over Øvre Kridt belemnitter fra den nordlige hemisfære anvendte han tidligt avancerede biometriske metoder for at undersøge variationen af belemnitpopulationer. Han foretog studie- og indsamlingsrejser i Danmark, Sverige, Tyskland, Frankrig, Polen, Rusland, Holland, Belgien, England, Nordirland og USA. Han havde et godt netværk blandt svenske, tyske, engelske, franske, belgiske og russiske palæontologer og stratigrafer og publicerede sammen med disse en lang række afhandlinger om $\varnothing v$ re Kridt.

Walter deltog ivrigt $\mathrm{i}$ internationalt, fagligt organisations- og komitéarbejde. Han var således dansk 
korrespondent i IGCP-Projektet "Mid-Cretaceous Events", samt medlem af »Working Group of the Scandinavian Subgroup of MCE« og »Working Group on Major Transgressions and Regressions « inden for samme projekt, 1975-1985. I 1972-1986 var han medlem af »Working Group on the Coniacian to Maastrichtian Stages " under "Subcommission on Cretaceous Stratigraphy « og formand for »Working Group on the Coniacian to Maastrichtian Stages « i 1986-1990, samt for "Subcommission on Cretaceous Stratigraphy" 1990-1994. Han var korresponderende medlem af "Subcommission on Cretaceous Stratigraphy « 19841990 , 'voting member' af samme subkommission fra juli 1994 -september 2000, og igen korresponderende medlem fra 20. september 2000 til sin død.

Han fungerede som kontaktperson mellem danske palæontologer og "International Palaeontological Association « siden 1983, var dansk korrespondent i IGCP Projekt No. 216 »Bio Events - Global Biological Events in Earth History « fra 1984 og medlem af den videnskabelige komité for "Société Géologique du Nord « i Frankrig.

Han var medarrangør af to internationale symposier afholdt i København: Cretaceous - Tertiary Boundary Events (1979) og Cretaceous Stage Boundaries (1983), og var medredaktør af symposiebindene. Han var endvidere medarrangør af »Field meeting of the Working Group on the Coniacian to Maastrichtian Stages « i 1987 i samarbejde med Natuurhistorisch Museum, Maastricht, Holland.

Walter deltog også flittigt i de administrative opgaver på museet. Han sad i museets bestyrelse i 19751978 og 1982-1983 og var bestyrer i 6 år fra 1983 til 1989 og vicebestyrer fra 1999. I samme periode var han medlem af og næstformand i Konsistoriums permanente Museumsudvalg. Han var medlem af det daværende Geologisk Centralinstituts bestyrelse 1976-1978 og 1980-1991, og var medlem af og næstformand for centralinstituttets forretningsudvalg $i$ 1976, 1977, 1980-1982 og 1985-1988.

Han var medlem af Dansk Geologisk Forening siden studieårene og var redaktør af Bulletin of the Geological Society of Denmark fra januar 1993 til sin død, samt medlem af redaktions-komiteen for tidsskriftet Lethaia siden januar 2000.

Walter var gennem 40 år en af de bedste banjospillere på den københavnske New Orleans jazzscene. De første 20-30 år af sin musikalske karriere tror jeg aldrig han tog en solo - ikke en gang ved private musiksammenkomster. Først i de senere år har jeg hørt ham rulle sig ud i mere solistiske indslag. Han havde et skarpt blik for både egne og andres evner og talenter og deres begrænsninger. Denne grundholdning prægede ham også i mange af livets andre gøremål.
Walter kunne være ret stædig og havde helt klart 'sine dage', hvor man skulle være lidt forsigtig med, hvad man sagde, eller - mere præcist - man skulle helst lade være med at sige noget. Til gengæld var det helt OK, at man drillede ham lidt med det bagefter. Denne stædighed eller vedholdenhed kunne imidlertid også komme til udtryk på en helt anden måde. Walter var i helt usædvanlig grad sine venners ven. Der var noget meget trygt ved at vide, at han altid var der, når man havde brug for ham. Han var totalt loyal, også selvom han ikke nødvendigvis var enig $\mathrm{i}$ ens synspunkter. Walter var en mand, man altid kunne betro sin ryg. Han stod altid op for en, når det var nødvendigt. Et finere skudsmål kan jeg ikke give en ven.

Finn Surlyk

\section{Publikationer}

Christensen, W.K. 1970a: Actinocamax primus Arkhangelsky from Scania, Sweden. Stockholm Contributions in Geology 21, 69-76.

Christensen, W.K. 1970b: A note on De Geer's belemnites from the Båstad area in Sweden. Geologiska Föreningens i Stockholms Förhandlingar 92, 503-504.

Christensen, W.K. 1971: Belemnitella propinqua propinqua (Moberg, 1885) from Scandinavia. Bulletin of the Geological Society of Denmark 20, 369-384.

Christensen, W.K. 1972: Structure of the guard in a species of Belemnitella. Neues Jahrbuch für Geolologie und Paläontologie 1972(6), 321-330.

Bergström, J., Christensen, W.K., Johansson, C. \& Norling, E. 1973a: An extension of Upper Cretaceous rocks to theSwedish west coast at Särdal. Bulletin of the Geological Society of Denmark 22, 83-154.

Christensen, W.K., Ernst, G., Schmid, F., Schulz, M.-G. \& Wood, C.J. 1973b: Comment on proposals for the designation of a neotype of the Upper Cretaceous Belemnites mucronatus Link, 1807. Z.N.(S.). 1160. Geologisches Jahrbuch A9, 4145.

Christensen, W.K. 1974a: Morphometric analysis of Actinocamax plenus from England. Bulletin of the Geological Society of Denmark 23, 1-26.

Surlyk, F. \& Christensen, W.K. 1974b: Epifaunal zonation on an Upper Cretaceous rocky coast. Geology 2(11), 529-534.

Christensen, W.K. 1975a: Upper Cretaceous belemnites from the Kristianstad area in Scania. Fossils and Strata 7, 69 pp.

Christensen, W.K. 1975b: Designation of lectotypes for Gonioteuthis westfalicagranulata and G. granulataquadrata. Paläontologische Zeitschrift 49, 126-134.

Christensen, W.K., Ernst, G., Schmid, F., Schulz, M.-G. \& Wood, C.J. 1975c: Belemnitella mucronata mucronata (Schlottheim, 1813) from the Upper Campanian: Neotype, biometry, comparisons, and biostratigraphy. Geologisches Jahrbuch A28, 27-57.

Christensen, W.K. \& Schulz, M.-G. 1976a: First record of Belemnellocamax balsvikensis (Brotzen, 1960) from NW Germany. Neues Jahrbuch für Geologie und Paläontoloige 1976, Mh. 9, 522-531. 
Christensen, W.K. 1976b: Palaeobiogeography of Late Cretaceous belemnites of Europe. Paläontologische Zeitschrift 50, 113-129.

Christensen, W.K. 1978: The Mid-Cretaceous of Scandinavia. Annals Museum Historié Naturelle Nice 4, 6 pp.

Christensen, W.K. 1979a: Maastrichtian belemnites from Denmark. In: Birkelund, T. \& Bromley, R.G. (eds): CretaceousTertiary Boundary Events. I. The Maastrichtian and Danian of Denmark, 42-44.

Christensen, W.K. \& Birkelund, T. (eds.) 1979b: CretaceousTertiary Boundary Events. II. Proceedings. 262 pp. Univ. of Copenhagen.

Kennedy, W.J., Hancock, J.M. \& Christensen, W. K. 1981a: Albian and Cenomanian ammonites from the island of Bornholm (Denmark). Bulletin of the Geological Society of Denmark 29, 203-244.

Combémorel, R., Christensen, W.K., Naidin, D.P. \& Spaeth, C. 1981b: Les Bèlemnites. Cretaceous Research 2, 283-286.

Christensen, W.K., Ernst, G., Schmid, F., Schulz, M.-G. \& Wood, C. 1982a: Belemnites mucronatus (Coleoidea): Proposed use of the plenary powers to attribute this name to Schlotheim, 1813 , and to designate a neotype in conformity with current usage. Z.N.(S.) 1160. Bulletin Zoolological Nomenclature $39,141-145$.

Christensen, W.K. 1982b: Late Turonian - early Coniacian belemnites from western and central Europe. Bulletin of the Geological Society of Denmark 31, 63-79.

Birkelund, T., Bromley, R., Christensen, W.K., Håkansson, E. \& Surlyk, F. (eds) 1983a: Symposium on Cretaceous Stage Boundaries. 210 pp. Geologisk Centralinstitut, University of Copenhagen.

Christensen, W.K. 1983b: The mid to Upper Cretaceous of southern Scandinavia. In: Birkelund, T., Bromley, R., Christensen, W.K., Håkansson, E. and Surlyk, F. (eds): Symposium on Cretaceous Stage Boundaries, 32-36.

Christensen, W.K. \& Hoch, E. 1983c: Actinocamax cf. manitobensis from the Kangerdlugssuaq area, southern East Greenland. Bulletin of the Geological Society of Denmark 32, 33 43.

Christensen, W.K. 1985: The Albian to Maastrichtian of Southern Sweden and Bornholm, Denmark: a Review. Cretaceous Research 5, 313-327.

Christensen, W.K. 1986a: Upper Cretaceous belemnites from the Vomb trough in Scania, Sweden. Sveriges geologiska Undersökning Ca57, 57 pp.

Christensen, W.K. 1986b: Scandinavia. In: Reyment, R.A. \& Bengtson, P. (Compilers): Events of the Mid-Cretaceous, 6870. Physics and Chemistry of the Earth 16. Oxford: Pergamon Press.

Christensen, W.K. \& Schmid, F. 1987: The belemnites of the Vaals Formation of the C.P.L. quarry at Hallembaye in Belgium - taxonomy, biometry and biostratigraphy. Geologiche Jahrbuch A94, 3-37.

Christensen, W.K. 1988a: Belemnella (Pachybelemnella) inflata (Arkhangelsky) from Nagoryany, USSR. Beitr. Paläont. Österr. 13, 77-82.

Christensen, W.K. 1988b: Upper Cretaceous belemnites of Europe: State of the art. In: Streel, M. \& Bless, M.J.M. (eds): The Chalk District of the Euregio Meuse-Rhine, 5-16. Maastricht: Natuurhistorisch Museum, and Liège: Laboratoires de Paléontologie de l'Universitè d'Etat.

Christensen, W.K., Håkansson, E. \& Surlyk, F. 1988c: Comment on 'Maastrichtian molluscan biostratigraphy and extinction patterns in a Cretaceous/ Tertiary boundary section exposed at Zumaya, Spain'. Geology 16, 764-765.

Robaszynski, F. \& Christensen, W.K. 1989: The Upper Campanian - Lower Maastrichtian chalks of the Mons basin, Belgium: a preliminary study of belemnites and foraminifera in the Harmignies and Ciply areas. Geol. Mijnb. 68, 391408.

Christensen, W.K. 1990a: Actinocamax primus Arkhangelsky (Belemnitellidae; Upper Cretaceous): Biometry, comparison and biostratigraphy. Paläontologische Zeitschrift 64, 7590.

Christensen, W.K., Bilotte, M. \& Melchior, P. 1990b: Upper Cretaceous belemnitellids from the Corbières, French Pyrenees. Cretaceous Research 11, 359-369.

Christensen, W.K. 1990c: Upper Cretaceous belemnite stratigraphy of Europe. Cretaceous Research 11, 371-386.

Kennedy, W.J. \& Christensen, W.K. 1991a: Coniacian and Santonian ammonites from Bornholm, Denmark. Bulletin of the Geological Society of Denmark 38, 203-226.

Tröger, K.-A. \& Christensen, W.K. 1991b: Upper Cretaceous (Cenomanian-Santonian) inoceramid bivalve faunas from the island of Bornholm, Denmark. With a review of the Cenomanian-Santonian lithostratigraphic formations of Bornholm and locality details. Danmarks Geologiske Undersøgelse A28, $47 \mathrm{pp}$. Copenhagen.

Christensen, W.K. 1991c: Belemnites from the Coniacian to Lower Campanian chalks of Norfolk and southern England. Palaeontology 34(3), 695-749.

Bardet, N., Bilotte, M. \& Christensen, W.K. 1992a: Nouveaux restes et révisions de faunas exceptionelles du Crétacé Supérieur audois: Les Belemnitellidae et Mosasauridae des Corbières. Bull. Soc. d'Etudes Scientifique de l'Aude 91, 11-21.

Christensen, W.K., Diedrich, C. and Kaplan, U. 1992b: Cenomanian belemnites from the Teutoburger Wald, NW Germany. Paläontologische Zeitschrift 66, 265-275.

Christensen, W.K. 1993a: Upper Cretaceous belemnitellids from the Båstad Basin, southern Sweden. Geologiska Föreningens i Stockholm Förhandlingar 115, 39-57.

Christensen, W.K., Bilotte, M. \& Hansotte, M 1993b: Additional Late Cretaceous belemnitellids from the Corbières, French Pyrenees and the ammonite biostratigraphy of the Santonian. Cretaceous Research 14, 101-106.

Christensen, W.K. 1993c: Actinocamax cobbani n. sp. from the Coniacian of Montana and Wyoming and the occurrence of Late Cretaceous belemnites in North America and Greenland. Journal of Palaeontology 67(3), 434-446.

Christensen, W.K. 1993d: Belemnocamax boweri Crick, an unusual belemnite from the Cenomanian of northwest Germany and eastern England. Bulletin of the Geological Society of Denmark 40,157-166.

Kennedy, W.J. \& Christensen, W.K. 1993e: Santonian ammonites from the Köpingsberg-1 borehole, Sweden. Bulletin of the Geological Society of Denmark 40, 149-156.

Christensen, W.K., Juignet, P., Breton, G. \& Cottard, N. 1993f: Bélemnites du Cretacé Supérieur de Normandie (France). Bulletin trimestrial de la Société Géologique de Normandie et Amis du Muséum du Havre 80, 29-44.

Christensen, W.K. 1994: Upper Cretaceous belemnites from Lonzée (SE Belgium) and their stratigraphical significance. Bulletin de 1'Institut Royal des Sciences Naturelles de Belgique, Sciences de la Terre 64, 151-158. 
Christensen, W.K. 1995a: Belemnitella from the Upper Campanian and Lower Maastrichtian Chalk of Norfolk, England. Special Papers in Palaeontology 51, 84 pp. London.

Jagt, J.W.M., Kennedy, W.J., Burnett, J.A., Christensen, W.K. \& Dhondt, A.V. 1995b: Santonian macrofauna and nannofossils from northeast Belgium. Bulletin de l'Institut Royal des Sciences Naturelles de Belgique, Sciences de la Terre 65, 127-137.

Michelsen, O., Christensen, W.K., Surlyk, F. \& Thomsen, E. 1996a: Stratigrafisk terminologi i dansksprogede artikler. Geologisk Tidsskrift 1996(2), 1-13.

Malchus, N., Dhondt, A.V., Tröger, K.-A. \& Christensen, W.K. 1996b: The 'Glauconie de Lonzée' (?Coniacian-Santonian) near Gembloux (SE Belgium), part I: Sedimentology, biostratigraphy, palaeoecology and -biogeography. Mitteilungen aus dem Geologisch-Paläontologischen Institut der Universität 77, 403-422.

Gale, A.S. \& Christensen, W.K. 1996c: Occurrence of the belemnite Actinocamax plenus in the Cenomanian of Les Lattes, SE France and its significance. Bulletin of the Geological Society of Denmark 43, 68-77.

Christensen, W.K. 1996d: A review of the Upper Campanian and Maastrichtian belemnite biostratigraphy of Europe. Cretaceous Research 17, 751-766.

Christensen, W.K. 1997a: The Upper Cretaceous belemnite family Belemnitellidae: Taxonomy and evolutionary history. Bulletin of the Geological Society of Denmark 44, 5988.

Christensen, W.K. \& Schulz, M.-G. 1997b: Coniacian and Santonian belemnite faunas from Bornholm, Denmark. Fossils and Strata 44, $73 \mathrm{pp}$.

Kennedy, W.J. \& Christensen, W.K. 1997c: Santonian to Maastrichtian ammonites from Scania, southern Sweden. Fossils and Strata 44, 75-128.

Christensen, W.K. 1997d: Palaeobiogeography and migration in the Late Cretaceous belemnite family Belemnitellidae. Acta Palaeontologica Polonica 42, 457-495.

Christensen, W.K. 1998a: Upper Campanian Belemnitella from Austria. Beiträge Paläontologie 23, 13-21.

Christensen, W.K. 1998b: Belemnitella from the lowermost Maastrichtian of Scania, southern Sweden. Bulletin of the Geological Society of Denmark 45, 11-21.

Kenndy, W.J., Landman, N.H., Christensen, W.K., Cobban, W.A. \& Hancock, J.M. 1998c: Marine connections in North America during the late Maastrichtian: palaeogeographic and palaeobiogeographic significance of Jeletzkytes nebrascensis Zone cephalopod fauna from the Elk Butte Member of the Pierre Shale, SE Dakota and NE Nebrasca. Cretaceous Research 19, 745-775.

Christensen, W.K. 1999: Upper Campanian and Lower Maastrichtian belemnites from the Mons Basin, Belgium. Bulletin de 1'Institut Royal des Sciences Naturelles de Belgique, Sciences de la Terre 69, 97-131.

Christensen, W.K. 2000a: Belemnitella schulzi sp. nov. from the uppermost Campanian and lowest Maastrichtian chalks of NW Germany and Denmark. Acta Geologica Polonica 50, 55-66.

Christensen, W.K., Hancock, J.M., Peake, N.B. \& Kennedy, W.J. 2000b: The base of the Maastrichtian. Bulletin of the Geological Society of Denmark 47, 81-85.

Christensen, W.K. 2000c: Gradualistic evolution in Belemnitella from the middle Campanian of Lower Saxony, NW Ger- many. Bulletin of the Geological Society of Denmark 47, 135-163.

Christensen, W.K. 2001: The Campanian-Maastrichtian Stage boundary. Bulletin of the Geological Society of Denmark 48, 208. Copenhagen.

\section{Resuméer, populærvidenskabelige artikler, ekskursionsførere, anmeldelser, nekrologer}

Christensen, W.K. 1969: Ivö Klack- ecological and stratigraphical observations. Meddelelser fra Dansk Geologisk Forening 19, 135-138.

Bergström, J., Laufeld, S. \& Christensen, W.K. 1972: Ekskursion til Skåne. Dansk Geologisk Forening Årsskrift for 1971, 111118.

Christensen, W.K. 1975: Palaeobiography of the Upper Cretaceous belemnites of Europe. Paläontologische Gesellschaft 45. Jahresversammlung in Hannover. Abstract.

Christensen, W.K. 1976: Review of R. Till: Statistical methods for the earth scientist. Macmillan, London 1974. Dansk Geologisk Forening, Årsskrift 1975, 56.

Christensen, W.K. 1977: Die marine Kreide. In: Hansen, M. \& Poulsen, V. (eds): Geologie auf Bornholm. Varv Exkursionsführer 1, 82-89.

Christensen, W.K. 1982: Review of Wiedmann, J. (ed.) 1979: Aspekte der Kreide Europas (Aspects of the Cretaceous in Europe). International Union of Geological Sciences A6, 680 pp. E. Schweitzerbart'sche Verlagsbuchhandlung. Geologiska Föreningens i Stockholms Förhandlingar 104, 106107.

Christensen, W.K. 1983: Review of Reyment, R.A. \& Bengtson, P. (eds) 1981: Aspects of mid-Cretaceous regional geology. 327 pp. Academic Press/London. Geologiska Föreningens i Stockholms Förhandlingar 104, 392-393.

Christensen, W.K., Surlyk, F. \& Sørensen, H. 1987a: Tove Birkelund, 28. november 1928 - 24. juni 1986. Dansk Geologisk Forening, Årsskrift 1986, 83-91.

Christensen, W.K., Surlyk, F. \& Sørensen, H. 1987b: Tove Birkelund, 28. november 1928 - 24. juni 1986. Københavns Universitet, Årbog 1986, 18-24.

Christensen, W.K. 1989: Upper Cretaceous belemnites of Europe: State of the art. In: Jerre, F. (ed.): Lundadagarne i Historisk Geologi och Paleontologi. Abstracts. Lund Publications in Geology 74, 7 only.

Håkansson, E. \& Christensen, W.K. 1990: Samme lag - forskellig alder. Varv 1990(2), 59-62.

Christensen, W.K. 1991a: The Upper Cretaceous of Bornholm. In: Arndorff, L. (ed.): Lundadagarna i Historisk Geologi och Paleontologi, II, Abstracts. Lund Publications in Geology 96,10 only.

Johnsen, O., Noe-Nygaard, A. \& Christensen, W.K. 1991b: Geologisk Museum - et centralt museum. Naturens Verden 1991(4), 161-168.

Jakobsen, S.L. \& Christensen, W.K. 1991c: Søpindsvin som danekræ. Varv 1991(1), 15-18.

Surlyk, F. \& Christensen, W.K. 1991d: Skrivekridt - idyl eller kaos. Carlsbergfondet, Årsskrift 1991, 33-38. 
Christensen, W.K. 1992: Origin of Late Cretaceous belemnitellids from the North American palaeobiogeographic Province. 4th International Cretaceous Symposium. Geol.Paläont. Institut.Hamburg 1992, Abstracts, 2 pp.

Christensen, W.K. 1993: Origin of Late Cretaceous belemnitellids from the North American palaeobiogeographic Province. In: Siverson, M. (ed.): Lundadagarna i Historisk Geologi och Paleontologi III, Abstracts, Lund Publication in Geology 109, 6 only.

Christensen, W.K. \& Schulz, M.-G. 1995a: Coniacian and Santonian belemnite faunas from Bornholm, Denmark. In: Månsson, K. (ed.): Lundadagarna i Historisk Geologi och Paleontologi IV, Abstracts, Lund Publication in Geologi 126, 8.

Christensen, W.K. 1995b: The Upper Campanian and Lower Maastrichtian Belemnitella succession of Norfolk. Second International Symposium on Cretaceous Stage Boundaries, Abstract Volume, 32 only. Institut Royal des Sciences Naturelles de Belgique, Brussels.

Kennedy, W.K., Christensen, W.K. \& Hancock, J.M. 1995c: Defining the base of the Maastrichtian and its substages. Report to the Maastrichtian Working Group at the Second International Symposium on Cretaceous Stage Boundaries, 16 pp. Brussels.

Christensen, W.K. 1996a: Upper Campanian and Maastrichtian belemnite stratigraphy of Europe: A review. Fifth International Cretaceous Symposium, Abstract Volume, 16 only. Freiberg University of Mining and Technology. Freiberg/ Sachsen, Germany.

Christensen, W.K. 1996b: Palaeobiogeography and migrations of the Late Cretaceous belemnites of the Northern Hemisphere. Colloque la Craie, Objet géologique, réservoir, materiax et paysage. Programme et Résumés, 24 only.

Christensen, W.K. 1997: Palaeobiogeography and migration in the Late Cretaceous belemnite family Belemnitellidae. In: Calner, H. \& Calner, M. (eds): Lundadagarne i Historisk Geologi och Paleontologi V, Abstracts, Lund Publications in Geology 134, 8 only.

Christensen, W.K. 1998a: Palaeobiogeography and migration in the Upper Cretaceous belemnite family Belemnitellidae. In: Wilson, J.R (ed.): 23. Nordiske Geologiske Vintermøde, Abstract Volume, 49 only.

Christensen, W.K. 1998b: Review of Proceedings of the Second International Symposium on Cretaceous Stage Boundaries (Rawson, P.F., Dhondt, A.V., Hancock, J.M. \& Kennedy, W.J. (eds)). Bulletin of the Geological Society of Denmark 44,128 only.

Christensen, W.K. 1998c: 'Tertiary', an informal term [Editor's Column]. Bulletin of the Geological Society of Denmark 44, 150 only.

Christensen, W.K. 1999a: Migration in the Upper Cretaceous belemnite family Belemnitellidae. In: Eriksson, M. (ed.): Lundadagarna i Historisk Geologi och Paleontologi VI, Abstracts, Lund Publications in Geology 144, 9 only.

Christensen, W.K. 1999b: Palaeobiogeography and migration in the Late Cretaceous belemnite family Belemnitellidae. Berichte der Geologischen Bundesanstalt 46, 28 only.

Christensen, W.K. 2000a: Gradualistic evolution in Belemnitella from the middle Campanian of Lower Saxony, NW Germany. Abstracts, 6th International Cretaceous Symposium, 20 only.

Christensen, W.K. 2000b: Change in Bulletin format. [Editor's column]. Bulletin of the Geological Society of Denmark 47, 28 only.

Christensen, W.K. 2000c: Living and fossil cephalopods. Review of Olóriz, F. \& Rodrìgue-Tovar, F.J. (eds): Advancing Research on Living and Fossil Cephalopods. Lethaia 33, 251-252.

Christensen, W.K. 2000d: Gradualistic evolution in Belemnitella from the middle Campanian of Lower Saxony, NW Germany. The Palaeontological Association, 44th Annual Meeting, Abstracts, Newsletters 45, 10 only.

Christensen, W.K. 2002: The Upper Cretaceous rocks and fossil faunas of Britain. Review of Mortimore, R.N., Wood, C.J. \& Gallois, R.W. 2001: British Upper Cretceous Stratigraphy. Geological Conservation Review Series 23, xx + 558 pp. Bulletin of the Geologocal Society of Denmark 49, 61-62. 